\title{
The Implementing of Participating Interest through Local Owned Enterprises in Sampang - Indonesia
}

\author{
Indra Yulianingsih ${ }^{1}$, Encik Muhammad Fauzan ${ }^{2}$, Yudi Widagdo Harimurti ${ }^{3}$ Azizah $^{4}$ \\ \{indra.yulianingsih@trunojoyo.ac.id ${ }^{1}$, encik.fauzan@trunojoyo.ac.id², \\ yudi.harimurti@trunojoyo.ac.id ${ }^{3}$,azizah@trunojoyo.ac.id $\left.{ }^{4}\right\}$ \\ Universitas Trunojoyo Madura, Indonesia ${ }^{1}$, Universitas Trunojoyo Madura, Indonesia ${ }^{2}$, Universitas \\ Trunojoyo Madura, Indonesia ${ }^{3}$, Universitas Trunojoyo Madura, Indonesia ${ }^{4}$
}

\begin{abstract}
Indonesian Government grants participating interest (PI) toward local government in capitalizing oil and gas exploitation, where areas have oil and gas exploitation blocks. The PI is set by the central government at $10 \%$. This research examines what is the form and regulation of the local government in participating interest in participating?. This research is a doctrinal legal research which has the aim of knowing the implementation of participating interest in Sampang Regency. Sampang Regency was used as the research location because it has oil and gas blocks in the waters of Sampang Regency. The results of this study indicate that participating interest in Sampang Regency is carried out by local owned enterprises, namely limited liability company of Geliat Sampang Mandiri (GSM Ltd). This company was formed through the Sampang Regency Local Laws Number 9 Year 2019. This laws for taking part in its participating interest.
\end{abstract}

Keywords: Participating Interest, Local Owned Enterprise, GSM Ltd

\section{Introduction}

The 1945 Indonesian Constitution in article 33 section (2) stated that the land, the waters and the natural resources within shall be under the powers of the State and shall be used to the greatest benefit of the people. The articel showed that the national economy is built on the basis of a people's economy. In this context, oil and natural gas are considered important and strategic for the state and dominate the lives of many people. Therefore, its utilization must be used for the greatest prosperity of the people. Oil and natural gas are one of the natural resources owned by the Indonesian people. However, not all of exploitation of mineral resources be carried out by Indonesian state. The state can delegate the exploitation to private legal entities or individual within the Indonesian mining jurisdiction with a Mining Authority, Contract of Work or Cooperation Agreement [1].

Natural resources are an important to human being. Consequently, the state must create the policies of the natural resource governance in order to give benefit for the people. It provides source of livelihood, income and a sense of meaning and identity to rural populations; they also constitute a source of revenue and authority to national and district governments, a source of wealth to national economic and political elites, and the basis for the provision of ecosystem services of local, regional, and global importance [2].

Indonesia regulate natural resources through Indonesian Law Number 22 Year 2011 about Oil and Natural Gas. This law regulates the management of oil and natural gas so that it is carried 
out effectively and efficiently, which includes upstream and downstream activities. Good management is expected to increase state revenue. Upstream Oil and Gas Business Activities are a form of management in the form of exploration and exploitation of oil and gas, which in this case can be carried out by business entities on the condition that they obtain approval from the Minister of Energy and Mineral Resources.

In the implementation of management and implementation, there are still many overlaps in terms of authority. This begins with a change in authority in local government. The dynamics of the formation of regulations regarding regional government were initially regulated in Law Number 32 of 2004 concerning Regional Government. Article 18 Paragraph (1) explains that regional governments can carry out exploration and exploitation activities of natural resources contained in the sea area. If an area in question has an administrative territorial area towards the sea, then this has opened the widest possible opportunity to manage these activities in its territory.

Furthermore, with the promulgation of Indonesian Law Number 23 Year 2014 concerning Regional Government, the change in authority previously held by the regional government as stipulated in Article 18 Paragraph (1) of Indonesian Law Number 32 Year 2004 becomes invalid. This is based on the existence of the provisions of article 14 paragraph (3) of Indonesian Law Number 23 Year 2014 which explains that matters previously related to oil and gas management are the authority of the regional government to become the authority of the central government.

The enactment of article 14 paragraph (3) of Indonesian Law Number 23 Year 2014 does not merely eliminate the authority of the regional government in implementing upstream business activities. The role of local governments is still owned by local governments as confirmed in article 11 Paragraph (3) of the Oil and Gas Law, in the form of environmental management and the determination of work areas, further explained in article 12 paragraph (1) of the Oil and Gas Law as regulated "the working area to be is offered to a business entity or a permanent establishment determined by the minister after consultation with the local government. " In environmental management, the authority of the regional government is also contained in article 12 Paragraph (2) letter e of Indonesia Law Number 23 Year 2014, in the attachment to the regulation, namely letter $\mathrm{k}$, regulates the division of government affairs in the environmental sector. The problem is how is the arrangement the Participating Interest (PI) by the central government and how is the implementation in the Local Government Sampang Regency. This research examines what is the form and regulation of the local government to obtain PI.

\section{Research Method}

This research was conducted using doctrinal legal research. Doctrinal research is research that assesses based on library research and statutory regulations [3]. Doctrinal research also is called normative research where the objects and sources are norms, concepts and doctrines that develop in legal thinking. The method of reasoning that is most often used in doctrinal research is deductive syllogistic reasoning [4]. Based on this, this research focuses more on the study of the laws and regulations established by the Indonesian government and the Local Government of Sampang. The laws and regulations studied are the 1945 Indonesian Constitution, Indonesian Law Number 22 Year 2011, Indonesian Law Number 23 Year 2014, Indonesian Government Regulation Number 35 Year 2004 and its amendments, Indonesian Government Regulation 
Number 79 Year 2010, Indonesian Government Regulation Number 54 Year 2017 and ndonesian Minister Regulation of Energy and Mineral Resources Number 37 Year 2016. In the study also analysis of local law namely Sampang Local Law Number 9 Year 2019. The selection of this local laws because researchers were directly involved in the formation of this local laws.

\section{Regulation of Participating Interest in Indonesia}

Participating interest is the right of the work area to get a share of management by the contractor based on an operating agreement with a set percentage. The contractor must be in the form of a corporate to carry out exploration and exploitation in a work area based on a cooperation contract to a special task force of implementing upstream oil and gas business activities. Regulating of participating interest in Indonesia, it regulate in Indonesian Government Regulation Number 35 Year 2004 as amendment in Indonesian Government Regulation Number 34 Year 2005 and second amendment by Indonesian Government Number 55 Year 2009. The regulation requires the contractor to offer a participating interest to regionalowned enterprises of $10 \%$. Regional-owned enterprises are required to respond to this offer a maximum of 60 days after the contractor offers it. If for 60 days there is no response from this regional-owned company, the contractor can offer it to the national company.

The definition of partipating interest can find out in the Indonesian Government Regulation Number 79 Year 2010 and Indonesian Minister Regulation of Energy and Mineral Resources Number 37 Year 2016. This term has means rights and obligations as Cooperation Contract Contractors, either directly or indirectly, in a work area. Participating interest is the proportion of production and exploration ownership in an oil and gas working area. Participating interest (PI) is the participation of business entities including regional-owned enterprises and permanent establishments in the management of upstream oil and gas through transfer of participating interest.

In implementing of participating interest, also regulate by Indonesian Minister Regulation of Energy and Mineral Resources Number 37 year 2016. The regulation stipulate the condition of regional-owned entreprises as implementing of Indonesian government regulation number 35 year 2004. Regional-owned entreprises must fullfil as regional companies that all ownership the shares are owned by the local government or limited liability company which is at least $99 \%$ (ninety nine percent) of the shares are owned by local government and remaining ownership its shares are wholly affiliated with the government regional. The companies must be legalized through regional regulations and it does not carry out business activities other than management participating interest.

The aim of the regional government through regional-owned enterprises is to gain participating interest so that local governments that have oil and gas exploitation work areas can benefit from managing oil and natural gas. The results of this participating interest will become regional income and be used for the welfare of the community. the rights obtained by this regional-owned enterprise are in the form of oil and gas production, a large portion of the acquisition of rights is equivalent to the obligations that must be carried out. The obligations that must be carried out are the obligation to develop, operate and carry out maintenance in oil and gas activities [5]. as follows:

There are important aspects that must be considered in implementing participating interest, 
1. For fields that are on land in 1 (one) province or offshore waters farthest to with 4 (four) nautical miles, a 10\% PI offer is awarded to 1 (one) Regionally Owned Enterprise which its formation is coordinated by the governor with involving regional regents / mayors the administration has an approved field development plan.

2. for fields that are in offshore waters with a distance of more than 4 (four) nautical miles up to 12 (twelve) nautical miles measured from the coastline to the sea independent, the $10 \%$ PI offer is given to the Business Entity Owned by the Provincial Region which is implemented coordinated by the governor.

3. for fields located on land and / or offshore waters that are in an administrative area of more than 1 (one) province, the implementation of the 10\% PI bid is carried out based on an agreement between the governor concerned who is coordinated by the governor whose territory covers most of the fields to be developed or Whereas as referred to in number 1 cannot be achieved within 3 (three) months from the date of request for appointment of Regional Owned Enterprises, the Minister shall determine the amount of participating interest to be offered to each provinces.

\section{Establishment of Regional Owned Enterprise in Sampang to obtain PI}

Sampang is one of the regencies in the Province of East Java, precisely on the island of Madura. In general, Madura island have an exceptionally large potential for oil resources. There are about 100 oil and gas blocks around the island of Madura. In Sampang Regency, there are around 14 oil and gas fields such as in Oyong off the coast of Camplong, Sumur Jeruk off the coast of Sreseh, Foram and Pollen wells off the coast of Ketapang, Mount Eleh well, Kedungdung District, and others. This is a tremendous potential and should be able to improve the welfare of the people of the island of Madura.

The local government should have taken the $10 \%$ PI offer by establishing a regional-owned enterprise. This formation must be carried out immediately by local governments that have oil and gas fields. This is certainly in line with the implementation of regional autonomy in Indonesia which aims to improve the welfare of the community in various fields. Although the management of oil and natural gas is not under the authority of local governments, regional governments can contribute through the $10 \%$ PI scheme.

Currently, many areas with oil and gas working areas have received less attention or have felt the positive impact of the exploitation of oil and natural gas in these areas. In fact, these areas are the areas most affected by the production of oil and natural gas. The continuous exploitation of oil and gas has resulted in the depletion of reserves stored in the bowels of the earth, especially those located in producing areas. As a result, the producing regions slowly but surely lose the reserves of natural oil and gas resources that are contained in the bowels of the earth in their territories [6].

Unfortunately, many regions are unable to participate in this PI because they need a large enough capital to get this $10 \%$ PI. In fact, not all local governments that have received Participating Interest (PI) rights are ready to anticipate receiving PI both in terms of funding, ability to do business and mastery of technology. From the funding side, for example, the Bojonegoro and Blora regencies are unable to meet the requirements for capital to be invested. Therefore, both of them took other private partners as investors to support funding [7].

This $10 \%$ PI is especially important for Sampang Regency and three other areas such as Bangkalan, Pamekasan and Sumenep, which are four regency on Madura Island. These four 
regencies have a high poor community, especially Sampang, which is the district with the highest poverty rate in East Java Province. This social condition is very contradicting with the abundant natural resources in Sampang Regency. Sampang people should also enjoy the results from natural resources, especially from oil and natural gas. The existence of this PI is a hope that poverty alleviation will be implemented in Sampang Regency soon.

The establishment of a regionally owned enterprise in Sampang Regency to obtain a $10 \%$ PI is a must. Through the Sampang Regency regional regulation number 9 of 2019 concerning the Establishment of a Regional Company Company Geliat Sampang Mandiri (GSM Ltd). This regional company was previously a regional business entity that could not manage the PI, because its status as a holding company was not a regular regional owned enterprise and the initial capital of this company came from an employee cooperative. For this reason, it is necessary to transfer capital from cooperatives to capital sourced from the local government to become a regionally owned business entity that can manage the $10 \%$ PI.

The existence of the regional company, GSM Ltd, is particularly important as a form of investment for the Sampang Regency in increasing its economic growth. This company was founded in 2008 based on the Sampang Regency Local Laws Number 8 Year 2008 concerning the Formation of GSM Ltd as amended several times, most recently by the Sampang Regency Local Laws Number 10 Year 2013 concerning the second amendment to the Sampang Regency Local Laws Number 8 Year 2008 regarding the Establishment of GSM Ltd.

In addition, the formation of this company is intended to control and manage the oil and gas business, infrastructure and industry, and services. Meanwhile, one of the goals is to ensure the effectiveness of the implementation of businesses engaged in the oil and gas, infrastructure, and industry, from accountable services through fair, healthy and transparent business mechanisms. This company in running its company has also been supported by two subsidiaries, namely Sampang Sarana Shorebase (SSS Ltd) through Sampang Regency Local Laws Number 18 Year 2007 concerning the Establishment of Regional Owned Enterprises in the Form of SSS Ltd and Sampang Mandiri Perkasa (SMP Ltd) through Sampang Regency Local Laws Number 3 Year 2010 concerning the Establishment of Regional Owned Enterprises in the form of SMP Ltd. The two companies in these regional regulations are both declared as regional owned enterprises and are formed through local laws.

Achieving aims and objectives GMS Ltd, it conducts business management activities of oil and gas both upstream business activities, downstream businesses and other supporting business activities for oil and gas in Sampang Regency and / or outside Sampang Regency in accordance with the statutory provisions applies. The existence of Indonesian Government Regulation Number 54 Year 2017 and Indonesian Minister Regulation of Energy and Mineral Resources obliges GSM Ltd to adjust these two regulations. So, in 2018 the local government began to conduct a study to form local regulations to replace the regional regulations that have regulated GSM Ltd. In 2019, Sampang Regency Local Laws Number 9 Year 2019 was issued in response to regional needs to obtain PI.

The formation of this regional regulation is intended to give this GSM Ltd regional company authority to control and manage the oil and gas business sector. Meanwhile, the objectives of establishing the GSM Ltd are:

a. conduct business to gain participating interest in the management of oil and gas in the regions through the formation of a subsidiary

b. carry out efforts to obtain dividends; and

c. carry out technology transfer and management as well as improvement and empowerment of human resources. 
Based on the objective of establishing GSM Ltd as a company owned by the Sampang regency, this company has met the requirements for obtaining a $10 \%$ PI. If the process of obtaining this PI is smooth, it will be able to increase local income for the development and welfare of the Sampang Regency community. The establishment of this regionally owned business entity can be used as an example for other regions in Indonesia or other countries where oil and gas fields are exploited and explored.

\section{Conclusion}

Participating Interest in the management of Oil and Gas in Indonesia is regulated in Article 2 of the Indonesian Minister Regulation of Energy and Mineral Resources Number 37 Year 2016, that regions are entitled to a Participating Interest of $10 \%$ in the management of Oil and Gas. The implementation of Participating Interest in the management of Oil and Gas in Sampang Regency based on these provisions has yet to be realized properly even though a local owned enterprise has been formed, namely GSM Ltd through Sampang Regency Local Laws Number 9 Year 2019. The Local Government of Sampang Regency must be able to pressure GSM Ltd is to realize the $10 \%$ PI to increase the revenue of the Region.

\section{References}

[1] R. Sarifudin, "Kewenangan Pemerintah Daerah Pengelolaan Partisipasi Interest (PI) Pada Sektor Migas," J. Sosio Sains, vol. 5, no. 2, pp. 128-139, 2019.

[2] H. M. Ravnborg and L. I. Gómez, "The Importance of Inequality for Natural Resource Governance: Evidence from Two Nicaraguan Territories," World Dev., vol. 73, pp. 72-84, 2015, doi: 10.1016/j.worlddev.2014.11.001.

[3] A. Yaqin, Legal Research and Writing. Kelana Jaya Selangor: Lexis Nexis, 2007.

[4] M. H. Hakim, "Pergeseran Orientasi Penelitian Hukum: Dari Doktrinal Ke Sosio-Legal," Syariah J. Huk. dan Pemikir., vol. 16, no. 2, p. 105, 2017, doi: 10.18592/sy.v16i2.1031.

[5] Z. S. Belanusa, R. Kartikasari, and A. Cahyadini, "Urgensi Penerapan Good Corporate Governance Pada Badan Usaha Milik Daerah Dalam Pengelolaan Minyak Dan Gas Bumi Di Indonesia," J. Jurisprud., vol. 10, no. 1, pp. 1-14, 2020, doi: 10.23917/jjr.v1.

[6] J. A. Setiawan, "Partisipasi Daerah Penghasil (Participating Interest) Di Wilayah Kerja (Blok) Masela," J. Komun. Huk., vol. 2, no. 2, pp. 188-210, 2016, doi: 10.1017/CBO9781107415324.004.

[7] A. Sholikin, "Otonomi Daerah dan Pengelolaan Minyak Bumi di Kabupaten Bojonegoro," J. Ilmu Adm., vol. XV, no. 1, pp. 35-50, 2018. 